\title{
Menghidupkan Kembali Sukma Bhinneka Tunggal Ika dan Pancasila
}

\author{
Adrian \\ Program Studi Hubungan Internasional, Universitas Nahdlatul Ulama, \\ Kalimantan Timur \\ andriberau7@gmail.com
}

\begin{abstract}
Differences are becoming the cause of conflict, intolerance, and disintegration in the life of the people and of the nation belong together. Many people are against and hate differences. Differences were viewed as enemies that has to be fought together. In the context of Indonesia, the problems it can bring are fortified by national slogans and bastions of unity and tolerance. In recent times, however, the national slogans and bastions seem to have lost their ability as bastions and lost their existence within people. The article aims to offer a better understanding and alternative solutions in revitalizing the values of Pancasila and Unity in Diversity, in this context the authors refer to "Sukma" as a means to prevent or minimize the practice of intolerance in society.
\end{abstract}

Keywords: Intolerance, Unity in Diversity, Bhinneka Tunggal lka, Pancasila.

\begin{abstract}
ABSTRAK
Perbedaan acapkali menjadi penyebab terjadinya konflik, intoleransi dan disintegrasi (perpecahan) dalam kehidupan bermasyarakat, berbangsa dan bernegara. Tak sedikit orang yang anti dan benci dengan perbedaan. Perbedaan seolah dipandang sebagai musuh yang harus diperangi secara bersama. Dalam konteks Indonesia, masalah-masalah yang dapat ditimbulkan oleh perbedaan tersebut dibentengi oleh semboyan dan dasar negara yang sarat akan nilai-nilai persatuan dan toleransi. Namun, belakangan ini semboyan dan dasar negara tersebut seolah kehilangan kemampuannya sebagai benteng dan kehilangan eksistensinya di tengah masyarakat. Hal tersebut melatarbelakangi tujuan artikel ini untuk memberikan pemahaman dan alternatif solusi dalam menghidupkan kembali nilai-nilai Pancasila dan Bhinneka Tunggal lka, dalam konteks ini penulis istilahkan sebagai "Sukma" sebagai alat untuk mencegah atau meminimalisir praktik intoleransi di masyarakat.
\end{abstract}

Kata Kunci: Intoleransi, Bhinneka Tunggal Ika, Pancasila.

\section{PENDAHULUAN}

Ragam dan maraknya praktik intoleransi yang terjadi belakangan ini, telah menimbulkan berbagai macam pertikaian dan perpecahan dalam masyarakat. Seperti, tindakan pelarangan pendirian rumah ibadah, penghancuran rumah ibadah, pelarangan perayaan keagamaan, penyebaran isu-isu intoleran dalam media massa, dan intoleransi dalam aspek kebijakan. Data survei Lembaga Survei Indonesia (LSI) menyatakan intoleransi masyarakat hari ini cukup tinggi, dimana data tersebut didukung oleh survei yang juga dilakukan oleh LSI tentang modal dan tantangan kebebasan sipil, intoleransi dan demokrasi di periode kedua pemerintahan Presiden Joko Widodo pada 8-17 September 2019 terhadap 1.550 responden. Menurut ketua LSI Djayadi Hanan, terdapat penurunan intoleransi religious-kultur sejak tahun 2010, namun berhenti pada tahun 2017. Intoleransi religius-kultur mengalami peningkatan setelah tahun 2017, khususnya dalam persoalan pembangunan rumah ibadah (CNN Indonesia, 2019). Selanjutnya, Imparsial menyebutkan bahwa telah terjadi 31 kasus intoleransi di Indonesia dalam tahun 2018 hingga 2019. Dari jumlah kasus tersebut, 
tindakan intoleransi yang paling banyak terjadi adalah pelarangan kegiatan ibadah, dimana sudah terjadi sedikitnya 12 kali. Selain tindakan diatas, urutan kedua menurut Imparsial adalah kasus pelarangan mendirikan rumah ibadah, dimana sudah terjadi sebanyak 11 kali (Beritasatu.com, 2019).

Ada banyak faktor yang melatar belakangi terjadinya praktik intoleransi di masyarakat antara lain faktor sosial-ekonomi, politik dan pemahaman keagamaan. Selain itu, rendahnya tingkat pemahaman dan pengamalan terhadap nilai-nilai Bhinneka Tunggal lka dan Pancasila juga menjadi faktor pendukung terjadinya praktik intoleransi. Pada dasarnya Bhinneka Tunggal lka dan Pancasila memiliki prinsipprinsip yang bisa menampung dan menerima semua warga masyarakat dari beragam latar belakang suku, budaya dan agama. Pancasila berasal dari gabungan nilai-nilai kebaikan yang universal, tidak memihak pada suku atau agama tertentu. Kandungan nilai Pancasila dapat diterima oleh seluruh lapisan masyarakat dan nilai-nilai tersebut (Hafsah, 2013) sesuai dengan situasi dan kondisi zaman. Pemahaman terhadap Bhinneka Tunggal Ika dan Pancasila secara mendalam akan menjadikan setiap individu bersikap toleran dan sebaliknya pengabaian terhadapnya akan membuat individu menjadi berlaku intoleransi.

\section{METODE PENELITIAN}

Penelitian ini menggunakan jenis penelitian deskriptif, yang mana jenis penelitian deskriptif merupakan penelitian yang dilakukan dengan memberi deskripsi mengenai suatu keadaan secara objektif, tujuan dari penelitian deskriptif adalah untuk menjawab permasalahan yang dihadapi saat ini. Data penelitian dalam tulisan ini menggunakan data sekunder yakni, data yang didapat secara tidak langsung dengan cara mencari data-data di sebuah buku, jurnal, website atau data-data dari sebuah instansi yang kemudian di analisis atau content analysis.

\section{PEMBAHASAN}

Menurut Hunsberger (1995) dalam tulisan Farid (2018), intoleransi merupakan tindakan negatif yang dilatari oleh simplifikasi palsu atau prasangka yang berlebihan (over generalized beliefs). Terdapat tiga komponen dalam prasangka tersebut: (1) komponen kognitif meliputi stereotip terhadap kelompok luar yang direndahkan, (2) komponen afektif merupakan bentuk sikap tidak suka yang mendalam terhadap kelompok luar dan (3) komponen tindakan negatif terhadap anggota kelompok luar, secara interpersonal maupun dalam ranah kebijakan politik dan sosial. Intoleran ditegaskan oleh PBB pada Declaration on the Elimination of All Forms of Intolerance and of Discrimination Based on Religion of Belief, dimana PBB mengatakan bahwa intoleransi dan diskriminasi pada agama diartikan sebagai pembedaan, pengabaian, larangan atau pengutamaan yang didasarkan pada agama atau kepercayaan yang tujuannya atau akibatnya meniadakan atau mengurangi pengakuan, penikmatan, atau pelaksanaan hak asasi manusia dan kebebasan-kebebasan atas dasar yang setara (Luqyana \& Sukmono, 2020, p. 77). Ada beberapa faktor yang melatar belakangi terjadinya praktik intoleransi antara lain sebagai berikut: 
1) Faktor Sosial-Ekonomi

Kesenjangan sosial yang sudah lama terjadi akan mudah menimbulkan kecemburuan atau kemarahan sosial. Para sosiolog mengatakan bahwa kesenjangan sosial dapat melahirkan social greavences (kegalauan dan kecemburuan sosial) terhadap golongan masyarakat yang memiliki standar ekonomi tinggi, terutama jika kekayaan tersebut diperoleh secara ilegal seperti korupsi, penyuapan, memalak uang negara dan lain sebagainya. Terciptanya social grievances mendorong individu dan kelompok untuk melaksanakan protes terhadap ketidakadilan yang sudah lama dihadapi. Protes tersebut dapat dilakukan secara sederhana seperti tidak mengikuti perkumpulan, enggan bergaul, sampai dengan mengerahkan diri dan orang-orang senasib untuk melaksanakan protes terhadap sistem yang dianggap tidak adil. Hal tersebut berkaitan pula dengan argumen Jose Casanova, dalam Public Religions in America 1994, bahwa ekonomi yang timpang dapat menumbuhkan perilaku agresif dan merupakan basis dari public religion atau agama sipil Amerika. Terjadinya ketimpangan kondisi ekonomi tersebut diakibatkan oleh kebijakan politik suatu negara yang berdampak secara tidak langsung terhadap masyarakat beragama. Hal tersebut mengakibatkan masyarakat beragama untuk mengalami privatisasi dalam beragama dan dikhawatirkan dapat mendorong kebencian terhadap golongan yang sejahtera. Selanjutnya, masyarakat melakukan protes secara terorganisasi untuk menuntut keadilan (Qodir, 2017, pp. 36-37).

2) Faktor Politik

Faktor politik memiliki hubungan timbal balik atau saling mempengaruhi dengan faktor sosial-ekonomi, misalnya kesenjangan ekonomi dapat mempengaruhi intoleransi politik dan sebaliknya adanya kesenjangan ekonomi juga dipengaruhi oleh adanya kebijakan atau struktur politik yang timpang. Sullivan (1981), mengemukakan aspek-aspek yang dapat memprediksi intoleransi politik yaitu pertama, determinan sosial, meliputi usia, status sosial, tingkat pendidikan, dan keberagaman. Kedua, determinan psikologis, meliputi variabel-variabel keperibadian seperti self-esteem, aktualisasi nilai, dogmatisme agama, serta kepercayaan pada orang lain. Terakhir, determinan politik, mencakup konservatisme, norma-norma umum dan persepsi terhadap ancaman (Wahyu \& Sa'id, 2020, p. 26). Peter Beyer, seorang sosiolog ternama, memberikan penjelasan bahwa kebijakan politik dunia (bagian politik globalisasi) yang mengalami perubahan pada zaman sekarang dan masa depan akan menghasilkan banyak perubahan dalam pola atau bentuk sikap keagamaan dan pengorganisasian keagamaan. Perubahan struktur yang dihasilkan oleh politik globalisasi akan memengaruhi bentuk-bentuk keagamaan di era kontemporer. Perbedaan yang jelas dalam masyarakat akan terlihat dari hasil globalisasi politik, dimana sebagian mendapatkan keuntungan dan sisanya tidak mendapatkan keuntungan yang memadai, sehingga menimbulkan perlawanan yang diorganisasikan oleh pihak-pihak yang merasakan ketidakadilan (Qodir, 2017). 
3) Faktor Pemahaman Keagamaan

Adanya kekeliruan paham dan kepercayaan berlebih terhadap suatu agama atau kelompok tertentu telah melahirkan pemahaman fanatik (fanatisme). Fanatisme merupakan sebuah perilaku atau pendapat ekstrim mengenai sebuah ajaran atau objek tertentu, dimana biasanya ajaran tersebut sering dikaitkan dengan konsep kepercayaan, dogma atau paradigma (Maress, n.d.). Menurut $\mathrm{KH}$. Wahid Hasyim, fanatik didefinisikan sebagai suatu kepercayaan membabi-buta terhadap suatu ajaran dan menolak segala pendapat oarang lain dari pada yang dianut. Pola pikir yang fanatik menjadikan seorang atau kelompok menjadi kaku dan susah untuk menerima keberagaman, dikarenakan merasa kelompok atau aliran sendirilah yang paling benar sedangkan kelompok atau aliran lain salah. Selain itu, pola pikir yang fanatik juga menjadikan seorang atau kelompok menjadi susah menerima dan mengamalkan nilai-nilai Pancasila dan semboyan Bhinneka Tunggal lka. Pemikiran yang fanatik ini tidak hanya dapat menyebabkan seorang atau kelompok bersifat intoleransi, akan tetapi pemikiran yang fanatik, dapat bertransformasi menjadikan seorang atau kelompok memiliki sikap radikalisme dan terorisme. Hal ini senada dengan yang disampaikan oleh Ketua Komisi Fatwa Majelis Ulama Indonesia (MUI), KH. Ma'ruf Amin, yang mengatakan bahwa fanatisme yang berlebihan menyebabkan tumbuh suburnya radikalisme.

\section{BHINNEKA TUNGGAL IKA}

Sejarah mencatat bahwa istilah Bhinneka Tunggal lka sudah ada sejak abad ke-8 dan 9 Masehi. Secara spesifik, istilah tersebut sudah digunakan semasa pimpinan dua dinasti yaitu Sailendra (Buddha) dan Sanjaya (Hindu) pada masa kerajaan Mataram Kuno, di Jawa Tengah. Pembangunan candi Prambanan (Hindu) dan Borobudur (Buddha) merupakan simbolisasi prinsip Bhinneka Tunggal Ika (Fahruddin, 2013:245). Dalam kutipan sloka Kakawin Arjuna Wiwaha bait 27.2 terdapat prinsip Bhinneka Tunggal Ika sebagai berikut:

Ndan kantenanya, haji, tan hana bheda sao hyao hyang Buddha rakwa

Siwarajadewa, kalih sameka sira sao pinakeupi dharma, rio dharma sima tuwi yan lepas adwitiya.

Terjemahan: Demikian kenyataannya, tuanku raja, tidak ada bedanya Hyang Buddha dengan Hyang Siwa, keduanya adalah Esa, yang diwujudnyatakan dalam dharma, dan di dalam dharma juga akan mencapai hakekatnya yang Esa (Zoetmulder, 1983:415437; Wiryamartana, 1990:124-128; Titib, 2004:9-10; dan Mertamupu, 2011:1) (Farisi, 2015, p. 131)

Dalam prinsip Bhinneka Tunggal Ika mengajarkan kepada manusia agar hidup damai dan terbuka dengan keberagaman, dengan menjunjung sikap saling menghargai satu sama lain (Toleransi). Meskipun manusia berbeda dari segala aspek, namun harus disadari bahwa manusia menyembah dan akan kembali kepada Tuhan yang sama, yaitu Tuhan Yang Maha Esa. Semboyan Bhinneka Tunggal lka memuat dua konsep penting yakni, "Bhinneka" dan "Tunggal Ika", dimana Bhinneka mengakui adanya keanekaragaman, sedangkan Tunggal Ika, menginginkan adanya kesatuan (Farisi, 2015, p. 132). Dengan demikian, dapat kiranya disimpulkan bahwa Bhinneka 
Tunggal Ika menginginkan manusia hidup saling berdampingan di tengah keberagaman dengan kesadaran akan persatuan dan kesatuan.

Pada mulanya, istilah Bhinneka Tunggal Ika menunjukkan semangat toleransi keagamaan, namun kemudian dijadikan sebagai semboyan bangsa Indonesia yang ditetapkan dalam Peraturan Pemerintah No.66 Tahun 1951 tentang Lambang Negara. Bhinneka Tunggal Ika berasal dari bahasa Sansekerta yang terdiri dari kata "Bhinneka" yang bermakna "berbeda-beda itu", "Tunggal" yang bermakna "satu" dan "Ika" yang bermakna "itu". Jadi, jika diartikan menjadi berbeda-beda itu, satu itu atau berbedabeda tetapi tetap satu jua (Pursika, 2009, p. 15). Kata "satu" disini tidak hanya merujuk pada "Tuhan yang satu dan negara yang satu" namun, kata "satu" dapat juga kita pahami bahwa kita satu yaitu sama-sama manusia dan kita satu sama-sama hidup di bumi.

Tulisan Lalonde (1994:1-8) dalam Farisi (2015, p. 134) menjelaskan bahwa istilah Bhinneka Tunggal Ika digunakan dalam berbagai konteks selain toleransi beragama, seperti konteks toleransi mengenai keberagaman fisik, budaya, bahasa, sosial, politik, ideologi, dan psikologi menuju sebuah persatuan dan kesatuan yang lebih kompleks, berdasarkan sebuah pengertian bahwa keberagaman memperkaya interaksi manusia. Pemahaman yang luas terhadap Bhinneka Tunggal lka akan membuat setiap orang untuk senantiasa bersifat toleran dan damai, namun sebaliknya, apabila Bhinneka Tunggal lka dipahami secara sempit, niscaya sifat toleran akan berjalan secara sempit pula. Toleransi merupakan nilai yang melekat dalam Bhinneka Tunggal lka itu sendiri. Jika setiap individu memahami hakikat Bhinneka Tunggal Ika, niscaya akan bersifat dan menjadi seorang yang toleran.

Kata toleransi berasal dari bahasa latin, yaitu tolerantia yang bermakna kelonggaran, kelembutan hati, keringanan dan kesabaran. Istilah toleransi merujuk pada sikap terbuka, lapang dada, suka rela dan kelembutan. United Nations Educational Scientific and Culture Organization (UNESCO) mengartikan toleransi sebagai sikap saling menghormati, menerima, dan menghargai ditengah keragaman budaya, kebebasan berekspresi, dan karakter manusia. Maka toleransi harus didukung oleh berbagai pengetahuan, termasuk keterbukaan, dialog, kebebasan berpikir dan agama (Ginting \& Aryaningrum, 2009, p. 3).

a) Pancasila

Dalam perumusan Pancasila terdapat berbagai macam perdebatan dan pertentangan, hingga pada persetujuan dan pengesahan. Terdapat empat tokoh yang terlibat dan menjadi pembicara dalam perumusan Pancasila yang berlangsung pada sidang BPUPKI pertama pada tanggal 29 Mei 1945. Keempat tokoh tersebut adalah, Mr. Muh Yamin, Ir. Soekarno, Ki Bagus Hadikusumo, dan Mr, Soepomo, dimana para tokoh tersebut memberikan usulan mengenai dasar negara menurut perspektif pribadi. Walaupun pada proses perumusan Pancasila terdapat perbedaan pendapat, hal tersebut dapat diatasi dan tak menurunkan semangat persatuan dan kesatuan demi mewujudkan Indonesia merdeka (Ristekdikti, 2016, pp. 51-52).

Setelah berakhirnya sidang pertama, sidang kedua BPUPKI yang dilakukan pada 10-16 Juli 1945 menyetujui naskah awal "Pembukaan Hukum Dasar" atau Piagam Jakarta. Pada alinea keempat Piagam Jakarta terdapat rumusan Pancasila sebagai berikut: 
1) Ketuhanan, dengan kewajiban menjalankan syariat Islam bagi pemelukpemeluknya.

2) Kemanusiaan yang adil dan beradab.

3) Persatuan Indonesia.

4) Kerakyatan yang dipimpin oleh hikmat kebijaksanaan dalam permusyawaratan perwakilan.

5) Keadilan sosial bagi seluruh rakyat Indonesia. (Ristekdikti, 2016, p. 53)

Namun, terdapat tuntutan dan penolakan dari beberapa pihak terhadap pasal satu pada kalimat setelah kata "Ketuhanan", karena dianggap tidak mewakili nilai-nilai dari agama yang lain, akan tetapi hanya mencerminkan agama Islam semata. Hal ini kemudian dapat diperbaiki dikarenakan adanya permintaan dari representatif Indonesia timur yang menemui Bung Hatta dan mempertanyakan 7 kata di belakang kata "Ketuhanan" ditunjukkan pada sila 1 di atas. Permintaan tersebut diterima dengan baik oleh para pendiri bangsa, sehingga 7 kata dibelakang sila 1 dihapus sesuai kesepakatan. Sila 1 diganti dengan istilah "Yang Maha Esa" untuk menghindari hambatan di masa depan (Ristekdikti, 2016, p. 57)

Bung Karno dalam pidatonya di depan BPUPKI pada tanggal 1 Juni 1945 menegaskan:

“... Bukan saja bangsa Indonesia berTuhan, tetapi masing-masing orang Indonesia hendaknya berTuhan, Tuhannya sendiri. Yang Kristen menyembah Tuhan menurut petunjuk Isa al-Masih, yang Islam menurut petunjuk Nabi Muhammad SAW. Orang Buddha menjalankan menurut kitab yang ada padanya. Tetapi marilah kita berTuhan. Hendaklah negara Indonesia ialah negara yang tiap-tiap orangnya dapat menyembah Tuhannya dengan leluasa, segenap rakyat hendaknya berTuhan, secara kebudayaan, yakni dengan tiada "Egoisme Agama" dan hendaknya negara Indonesia satu negara yang berTuhan" (Muhammad Jazir, 2013, p. 82).

Buku Ismatu Ropi yang berjudul "Religion and Regulation in Indonesia" menjelaskan bahwa ketika awal Pancasila diterima sebagai dasar negara dan bagian dari konstitusi, sila pertama dalam Pancasila bermakna cukup "netral". Sila pertama menjadi pemersatu semua golongan masyarakat, khususnya kelompok agama-agama utama yaitu Islam, Kristen, Hindu, dan Buddha. Masing-masing merasa sila tersebut mewakili aspirasi religius mereka dan tidak ada pihak yang merasa dikhususkan dengan bunyi sila tersebut. Selanjutnya sebagian tokoh Kristen seperti Helmut Rosin dan T.B. Simatupang menjelaskan makna sila pertama. Menurut mereka, sila pertama dibuat untuk memayungi semua agama, bukan hanya satu agama. Karena itulah istilah yang digunakan Soekarno bukan "Tuhan" secara personal, tapi "Ketuhanan". Hamka juga dalam bukunya yang berjudul "Urat Tunggang Pantjasila" menegaskan bahwa Pancasila tidak kontradiktif dengan Islam dan sila pertama tidak lebih dari terjemahan konsep Islam tentang tauhid. Tauhid berarti esa atau tunggal, inti ajaran tauhid adalah pengesaan terhadap Tuhan. Dengan kata lain "Ketuhanan Yang Maha Esa” adalah kata lain dari tauhid (Assyaukanie, 2018, p. 33).

Pancasila merupakan dasar negara, pandangan hidup, ideologi nasional, pemersatu dalam perkehidupan kebangsaan dan kenegaraan, dan sumber dari sumber segala hukum sejak pengesahan UUD Negara Republik Indonesia 
pada 18 Agustus 1945. Meskipun UUD telah mengalami berbagai perubahan sejak proklamasi, pembukaan UUD selalu menegaskan bahwa kemerdekaan kita harus dibangun atas dasar Pancasila yang mengandung lima sila yang saling berkaitan. Kelima sila itu memiliki landasan ontologis, epistemologis, dan aksiologis yang kuat, memiliki dimensi historisitas, rasionalitas dan aktualitas yang relevan (Latif, 2013, p. 75).

Nilai-nilai Pancasila sebagai landasan etika dan moral yang mendasari kehidupan berbangsa dan bernegara sesungguhnya telah tertuang dalam ketetapan MPR Nomor VI/MPR/2001 tentang etika kehidupan berbangsa, yang meliputi etika sosial budaya, etika politik pemerintahan, etika ekonomi dan bisnis, etika keilmuan, etika lingkungan, serta etika penegakan hukum yang berkeadilan. Dalam bidang politik dan pemerintahan, nilai-nilai Pancasila harus dapat memberi perspektif etika dan moral politik dan pemerintahan yang lebih demokratis. Dalam bidang hukum, nilai-nilai Pancasila juga harus memberi perspektif etik dan moral dalam penegakan hukum dalam tiga aspek: substansi, struktur dan kultur hukum. Sesuai ketetapan MPR Nomor XVIII/MPR/1998 Pancasila adalah dasar negara, dan Pancasila adalah sumber dari segala sumber hukum. Dalam bidang sosial-budaya, nilai-nilai Pancasila juga menjadi perspektif etik dan moral dalam kehidupan sosial dan keberagaman budaya Indonesia. Selanjutnya dalam bidang perekonomian, nilai-nilai Pancasila juga dapat memberikan perspektif positif jika kita semua memiliki komitmen melaksanakan ketentuan Pasal 33 UUD Tahun 1945, dan ketetapan MPR No XVI/MPR/1998 tentang politik ekonomi dalam rangka demokrasi ekonomi, sebagai pelaksanaan sila kelima Pancasila yakni "Keadilan Sosial Bagi Seluruh Rakyat Indonesia" (Hamid, 2013).

b) Alternatif Solusi Dalam Menghidupkan Kembali Sukma Bhinneka Tunggal Ika dan Pancasila

Adapun alternatif solusi yang ditawarkan dalam artikel ini antara lain adalah pertama, menghidupkan seminar atau diskusi Kebhinekaan dan Kepancasilaan di tengah masyarakat. Seminar atau diskusi ini tidak hanya dilakukan dalam dunia pendidikan atau dilakukan oleh para akademisi dan aktivis saja, agar tak hanya segelintir orang yang dapat memahami Bhinneka Tunggal Ika dan Pancasila, akan tetapi harus melibatkan seluruh lapisan masyarakat. Misalnya, di tingkat desa/kampung dapat dilakukan oleh Kepala Desa/Kampung, di tingkat Kecamatan dapat dilakukan oleh Camat dan seterusnya. Juga dapat dilakukan oleh organisasi-organisasi yang bergerak dalam bidang Kebhinekaan dan Kepancasilaan dengan melibatkan masyarakat.

Kedua, sosialisasi. Sosialisasi ini dapat dilakukan secara langsung bertemu dengan masyarakat maupun secara tidak langsung dengan menggunakan atau memanfaatkan teknologi yang ada misalnya, melalui media massa dan televisi. Teknik sosialisasi secara terstruktur, tersusun dan berskala besar adalah cara yang baik dan penting untuk menumbuhkan kembali nilainilai Bhinneka Tunggal Ika dan Pancasila di masyarakat. Sosialisasi tersebut harus mengutamakan kesadaran dan partisipasi masyarakat ketimbang paksaan atau indoktrinasi (Masrukhi \& Wahono, 2019, p. 183). Perspektif sosiologi menyatakan bahwa sosialisasi dilakukan dalam dua pola, yakni 
sosialisasi represif dan partisipatoris. Sosialisasi represif dilakukan melalui komunikasi yang bersifat satu arah, non verbal dan berisi perintah, sehingga penekannya pada kehendak si penyampai pesan. Sedangkan sosialisasi partisipatoris diletakkan pada komunikasi dan interaksi yang bersifat verbal dan terjadi dua arah secara timbal balik. Setidaknya ada tiga dimensi efek yang ingin dicapai dengan adanya sosialisasi yakni efek kognitif, efek afektif dan efek psikomotorik (Hafsah, 2013, pp. 5-6).

Ketiga, Pendidikan Berbasis Keluarga. Keluarga sebagai tingkat paling kecil memiliki peran penting dalam menanamkan dan mengajarkan nilai-nilai Bhinneka Tunggal lka dan Pancasila kepada para anggota keluarganya terutama anak, mengingat penanaman nilai memerlukan proses yang panjang dan tak semata menjadi tanggung jawab sekolah tapi juga tanggung jawab keluarga tertutama orang tua. Di tingkat ini merupakan pondasi awal untuk tahapan selanjutnya yang lebih luas (masyarakat dan negara). Masa keemasan seorang anak adalah pada masa usia dini, dimana perkembangan otak mereka sedang berada di puncak. Hal ini dapat membantu pertumbuhan dan perkembangan dalam aspek kognitif, fisik, motorik, sosial dan emosi. Masa keemasan tersebut menjadi pondasi dasar-dasar pembentukan kepribadian seorang anak yang akan berkembang menjadi pilar identitasnya pada saat dewasa (Arriani, 2019), sehingga ketika seorang anak berada atau terjun pada tingkatan yang lebih luas, anak tersebut tidak mudah terpengaruh oleh pemahaman-pemahaman yang keliru dan sesat.

Kokotiasa (Budiyono \& Kokotiasa, 2013) menjelaskan bahwa Pancasila sebagai dasar negara dan pandangan hidup bangsa wajib untuk dihidupkan kembali atau singkatnya revitalisasi. Pentingnya revitalisasi tersebut dikarenakan Pancasila adalah asas dan landasan utama dalam menertibkan kehidupan bermasyarakat, berbangsa dan bernegara. Penguatan penerapan nilai-nilai Pancasila dalam masyarakat merupakan bentuk revitalisasi yang konstruktif, dimana semua komponen bangsa mulai dari para aktor lembaga eksekutif, institusi pendidikan, lingkungan, sampai keluarga memiliki tanggung jawab untuk mengimplementasikan dan saling mengajarkan nilai-nilai Pancasila. Pancasila merupakan hasil kesepakatan bersama yang mewajibkan semua masyarakat Indonesia untuk mengimplementasikannya dan menjauhi semua perilaku yang bertentangan.

\section{KESIMPULAN}

Rendahnya tingkat pemahaman dan pengamalan terhadap nilai-nilai Bhinneka Tunggal Ika dan Pancasila, serta adanya beberapa faktor pendukung lainnya telah melahirkan ragam jenis praktik intoleransi dalam kehidupan bermasyarakat dan bernegara. Mestinya nilai-nilai Bhinneka Tunggal lka dan Pancasila yang telah disepakati secara bersama, dapat dijadikan sebagai pedoman dan acuan dalam kehidupan terutama dalam aspek pembentukan kebijakan, agar kebijakan yang lahir tidak bersifat timpang baik dalam kebijakan sosial, ekonomi dan politik. Setiap orang atau kelompok seharusnya menyelaraskan tindakan mereka dengan nilai-nilai yang telah disepakati secara bersama. Menurut Kaelan (2002) dalam Masrukhi \& Wahono (2019), pengamalan nilai-nilai yang telah disepakati secara bersama terdiri dari dua macam, pengamalan subjektif dan objektif. Pengalaman subjektif merujuk pada 
pelaksanaan dalam pribadi setiap individu manusia, sedangkan pengamalan objektif merujuk pada realisasi pelaksanaan setiap aspek pengelolaan negara di bidang legislatif, eksekutif dan yudikatif. Selain ketiga bidang tersebut, pelaksanaan juga dilakukan dalam bidang kenegaraan, khususnya dalam realisasi bentuk peraturan perundang-undangan negara Indonesia. Pembudayaan nilai-nilai Pancasila harus dipahami, namun harus didukung pula oleh implementasinya dalam kehidupan bermasyarakat dan bernegara.

\section{REFERENSI}

Arriani, F. (2019). Orang Tua Sebagai Penanam Nilai Pancasila Untuk Anak Usia Dini Di Era Digital. Journal Of Early Childhood Education, 1(2).

Assyaukanie, L. (2018). Akar-akar Legal Intoleransi dan Diskriminasi Di Indonesia. Jurnal Maarif Intitute, 13(2).

Beritasatu.com. (2019). Indonesia Dinilai Darurat Intoleransi. https://www.google.com/amp/s/amp.beritasatu.com/politik/585817/indonesiadinilai-darurat-intoleransi

Budiyono, \& Kokotiasa, W. (2013). Aktualisasi Nilai-Nilai Pancasila (Mencari Model Pendidikan Pancasila Di Perguruan Tinggi). Jurnal Prodi PPKn, 2(1), 1. http://ejournal.unipma.ac.id/index.php/citizenship/article/download/3431/1897

CNN Indonesia. (2019). LSI: Intoleransi di Era Jokowi Masih Tinggi. https://m.cnnindonesia.com/nasional/20191103183341-32-445250/lsi-intoleransidi-era-jokowi-masih-tinggi

Farid, M. (2018). Memahami Intoleransi Dalam Ruang Publik. Geotimes. https://geotimes.co.id/opini/memahami-intoleransi-dalam-ruang-publik/

Farisi, M. I. (2015). Transformasi Konsep Bhinneka Tunggal Ika di Indonesia: Dari Politik Dinasti ke Politik Pendidikan. Jurnal Kajian Sejarah Dan Pendidikan, 3, 132.

Ginting, R., \& Aryaningrum, K. (2009). Toleransi Dalam Masyarakat Plural. Majalah IImiah Lontar, 23(4), 3. https://doi.org/10.26877//tr.v23i4.665

Hafsah, M. J. (2013). Strategi Pembudayaan Nilai-nilai Pancasila Di Bidang Pendidikan dan Budaya Dalam Perspektif Ke-Indonesiaan. In 1954- Sudjito, Surono, \& U. G. M. P. S. Pancasila (Eds.), Prosiding Kongres Pancasila V, 2013: strategi pembudayaan nilai-nilai Pancasila dalam menguatkan semangat ke-Indonesia-an (pp. 5-6). PSP Press, Universitas Gadjah Mada.

Hamid, A. F. (2013). Strategi Pembudayaan Nilai-nilai Pancasila dalam menguatkan semangat ke-Indonesiaan. In 1954- Sudjito, Surono, \& U. G. M. P. S. Pancasila (Eds.), Prosiding Kongres Pancasila V, 2013: strategi pembudayaan nilai-nilai Pancasila dalam menguatkan semangat ke-Indonesia-an. PSP Press, Universitas Gadjah Mada.

Latif, Y. (2013). Membumikan Etika Pancasila Dalam Penyelenggaraan Negara. In 1954- Sudjito, Surono, \& U. G. M. P. S. Pancasila (Eds.), Prosiding Kongres 
Pancasila V, 2013: strategi pembudayaan nilai-nilai Pancasila dalam menguatkan semangat ke-Indonesia-an (p. 75). PSP Press, Universitas Gadjah Mada.

Luqyana, Y. D., \& Sukmono, F. G. (2020). Isu Intoleransi dan Video Akun Menjadi Manusia. Jurnal Audiensi, 1(1).

Maress, B. (n.d.). Teori Fanatisme Dalam Psikologi - Pengaruh. DokterPsikologi.Com. https://dosenpsikologi.com/teori-fanatisme-dalam-psikologi

Masrukhi, \& Wahono, M. (2019). Model Ikhtiar Pembudayaan Nilai-nilai Pancasila Dikalangan Masyarakat Desa. Jurnal Bhineka Tunggal Ika: Kajian Teori Dan Praktik PKN, 6(2).

Muhammad Jazir, A. (2013). Pancasila: Harmonisasi Agama, Ekonomi dan Budaya. In 1954- Sudjito, Surono, \& U. G. M. P. S. Pancasila (Eds.), Prosiding Kongres Pancasila V, 2013: strategi pembudayaan nilai-nilai Pancasila dalam menguatkan semangat ke-Indonesia-an. PSP Press, Universitas Gadjah Mada.

Pursika, I. N. (2009). Kajian Analitik Terhadap Semboyan "Bhinneka Tunggal Ika". Jurnal Pendidikan Dan Pengajaran, 42, 15.

Qodir, Z. (2017). Intoleransi dan Sektarianisme Keagamaan: Sebuah Survey Literatur. Konfrontasi: Jurnal Kultur, Ekonomi Dan Perubahan Sosial, 4(2). https://doi.org/https://doi.org/10.33258/konfrontasi2.v6i2.27

Ristekdikti. (2016). Menelusuri Konsep dan Urgensi Pancasila dalam Arus Sejarah Bangsa Indonesia. In Pendidikan Pancasila untuk Perguruan Tinggi (pp. 5152,53,57). Direktorat Jendral Pembelajaran dan Kemahasiswaan.

Wahyu, A. M., \& Sa'id, M. (2020). Semakin Religius, Semakin Intoleran? Peran Kepercayaan Politik Sebagai Variabel Moderator. Jurnal Sosial Dan Humaniora, $9(1)$. 